\title{
KELAYAKAN INVESTASI PERLUASAN \\ PABRIK PENGGILINGAN PLASTIK PD XYZ
}

\author{
Hartiwi Prabowo \\ Management Department, School of Business Management, BINUS University \\ Jln. K.H. Syahdan No. 9, Palmerah, Jakarta Barat 11480 \\ Hartiwi2200@binus.ac.id
}

\begin{abstract}
PD. PENGGILINGAN PLASTIK XYZ is a company engaged in the manufacturing industry. Recently, demands for products are increasing and the company finds it difficult to meet the demands. Therefore, the company wants to expand the factory to increase output of the products. The purpose of this study is to determine whether the expansion of businesses that want to run is well-worth in terms of financial and nonfinancial aspects. The research method used is descriptive qualitative and quantitative methods. Qualitative descriptive analysis method is used to analyze the legal, technical/operations, markets and marketing, management/organizational, economic, social and environmental impacts. Quantitative descriptive analysis method is used to analyze the financial aspects, the market and marketing. The results of the feasibility study of the factory expansion from the financial aspect refer to an optimistic scenario assumptions and moderate, and worthy to do. Similarly, the non-financial aspects, all aspects point out that the expansion of the factory is feasible to do. By this, the company is expected to maintain a stable supply of raw materials, because, if the supply of raw materials is interrupeted, the operation cannot run.
\end{abstract}

Keywords: feasibility, investment, expansion

\begin{abstract}
ABSTRAK
PD PENGGILINGAN PLASTIK XYZ merupakan perusahaan yang bergerak di industri manufaktur. Semakin hari permintaan akan produk semakin meningkat dan perusahaan mengalami kesulitan untuk memenuhi permintaan tersebut. Oleh karena itu perusahaan ingin melakukan perluasan pabrik guna meningkatkan output produk. Tujuan penelitian ini adalah untuk mengetahui layak atau tidaknya perluasan usaha yang ingin dijalankan ditinjau dari aspek keuangan dan non keuangan. Metode penelitian yang digunakan adalah metode deskriptif kualitatif dan kuantitatif. Metode analisis deskriptif kualitatif digunakan untuk menganalisis aspek hukum, teknis/ operasi, pasar dan pemasaran, manajemen/ organisasi, ekonomi sosial dan AMDAL. Metode analisis deskriptif kuantitatif digunakan untuk menganalisis aspek keuangan, aspek pasar dan pemasaran. Hasil penelitian kelayakan investasi perluasan pabrik dari aspek keuangan menunjuk pada asumsi skenario optimis dan moderat, layak untuk dilakukan. Demikian dengan aspek non keuangan, semua aspek menunjuk bahwa perluasan pabrik dapat dilakukan. Dengan ini, diharapkan perusahaan dapat menjaga kestabilan pasokan bahan baku karena jika pasokan bahan baku terganggu, dapat menyebabkan operasi perusahaan tidak dapat berjalan.
\end{abstract}

Kata kunci: kelayakan, Investasi, perluasan usaha 


\section{PENDAHULUAN}

Salah satu peluang bisnis yang dipandang sebelah mata oleh kebanyakan orang dan dapat memberikan banyak keuntungan adalah industri daur ulang plastik. Walaupun usaha daur ulang plastik ini merupakan usaha yang bergelut dengan barang-barang bekas, cukup menjanjikan dan dapat memberikan banyak keuntungan, baik untuk diri sendiri yang dapat berupa keuntungan secara materi maupun bagi orang lain yang dapat berupa penambahan lapangan pekerjaan. Selain itu, usaha pendaur ulangan plastik ini dapat membantu mengurangi dampak pemanasan global dengan mengolah limbah plastik yang sukar membusuk karena bahan dasar yang digunakan oleh pabrik pendaur ulangan plastik adalah barang bekas pakai (limbah plastik) yang berbahan dasar plastik seperti: ember, kursi, meja, kemasan minuman berupa gelas, mainan anak anak, kemasan shampoo, gayung, dan barang lain berbahan dasar plastik yang sesuai dengan spesifikasi. Hasil pendaur ulangan sampah plastik yang telah menjadi barang siap pakai dijual dengan harga yang relatif murah sehingga membuat konsumen (industri manufaktur) tertarik. Oleh karena itu, usaha ini dapat dikatakan merupakan usaha yang menjanjikan.

PD. PENGGILINGAN PLASTIK XYZ yang bergerak pada industri daur ulang plastik adalah perusahaan yang mengelola limbah plastik sampai menjadi serpihan daur ulang plastik (sampah plastik yang digiling) untuk dijual kembali kepada pabrik pengolah serpihan daur ulang plastik untuk dicetak menjadi biji plastik atau langsung dicetak menjadi barang jadi. Pengangkutan bahan bahan dasar berupa limbah plastik dari lapak pengumpul limbah plastik dan pengiriman serpihan daur ulang plastik dikirim ke pabrik penghasil biji plastik atau pabrik penghasil barang jadi menggunakan kendaraan angkutan berjenis Truck colt diesel.

PD. PENGGILINGAN PLASTIK XYZ sudah berdiri sejak tahun 1984 dan sudah berasaskan hukum. Perusahaan dagang ini sudah memiliki nama yang cukup kuat dalam industri daur ulang plastik. Hal itu disebabkan karena selain umur perusahaan yang sudah mencapai 25 tahun, tetapi juga kualitas serpihan daur ulang plastik yang dihasilkan sangatlah baik. Penilaian kualitas serpihan daur ulang plastik dapat dinilai dari tingkat kebersihan serpihan dan campuran barang barang yang dimasukkan ke dalam mesin penggilingan. Umumnya campuran yang dimasukan ke dalam mesin penggilingan merupakan barang-barang yang berkualitas baik sehingga perusahaan yang mengelola serpihan daur ulang plastik tidak mengalami kesulitan dalam mengelola serpihan daur ulang plastik menjadi biji plastik atau menjadi barang jadi. Oleh karena itu, biji plastik atau barang jadi yang dihasilkan juga akan memiliki kualitas yang baik.

Permintaan akan serpihan daur ulang plastik yang dihasilkan oleh PD. PENGGILINGAN PLASTIK XYZ semakin hari semakin meningkat (Tabel 1). Ini karena kualitas dan kebersihan serpihan daur ulang plastik yang dihasilkan sangat baik, terlebih lagi banyak pabrik pengolah serpihan daur ulang plastik menjadi biji plastik atau barang jadi sulit menemukan kualitas serpihan daur ulang plastik yang berkualitas baik. Serta banyaknya pesaing yang mengalami kejatuhan membuat permintaan akan serpihan daur ulang plastik meningkat. Peningkatan permintaan terhadap serpihan daur ulang plastik sering membuat PD. PENGGILINGAN PLASTIK XYZ mengalami kesulitan dalam memenuhi permintaan dari pabrik penghasil biji plastik.

Tabel 1 Data Total Penjualan per Tahun

\begin{tabular}{|l|c|c|c|c|c|}
\hline Tahun & 2006 & 2007 & 2008 & 2009 & 2010 \\
\hline KG & 754.264 & 979.123 & 1.044 .039 & 1.036 .463 & 1.070 .226 \\
\hline
\end{tabular}

Sumber: PD. PENGGILINGAN PLASTIK XYZ 
Meningkatnya permintaan terhadap serpihan daur ulang plastik maka pemilik PD. PENGGILINGAN PLASTIK XYZ melihat perlu dilakukannya pengembangan usaha. Hal ini juga didukung oleh pertumbuhan permintaan produk bahan baku plastik yang tidak terlalu terpengaruh oleh krisis global. Pengembangan usaha yang dimaksud yaitu dengan penambahan satu unit mesin giling untuk menambah hasil produk akhir dan perluasan lahan yang digunakan untuk menempatkan mesin giling tambahan, tempat penyimpanan bahan baku, tempat pensortiran, tempat mencuci serpihan daur ulang plastik dan tempat untuk menjemur serpihan daur ulang plastik setelah dicuci.

Atas dasar latar belakang masalah tersebut, maka penulis tertarik untuk mengetahui kelayakan investasi perluasan pabrik penggilingan plastik XYZ. Tujuan dari penelitian ini adalah untuk mengetahui kelayakan investasi perluasan pabrik dari aspek keuangan dan non-keuangan.

\section{Tinjauan Pustaka}

\section{Pengertian Kewirausahaan}

Menurut pendapat Zimmerer dan Scarborough (2004, p3) "Wirausahawan adalah orang yang menciptakan sebuah bisnis baru dengan mengambil resiko dan ketidakpastian demi mencapai keuntungan dan pertumbuhan dengan cara mengidentifikasi peluang dan menggabungkan sumber daya yang diperlukan untuk mendirikannya.”

Menurut pendapat Kasmir (2006, p16) "Wirausahawan (entrepreneur) adalah orang yang berjiwa berani mengambil risiko untuk membuka usaha dalam berbagai kesempatan.” Berjiwa berani mengambil resiko artinya bermental mandiri dan berani memulai usaha, tanpa diliputi rasa takut atau cemas sekalipun dalam kondisi tidak pasti.

Menurut pendapat Peter F. Drucker yang dikutip oleh Kasmir (2006, p17) "kewirausahaan merupakan kemampuan dalam menciptakan sesuatu yang baru dan berbeda.” Pengertian ini mengandung maksud bahwa seorang wirausahawan adalah orang yang memiliki kemampuan untuk menciptakan sesuatu yang baru, berbeda dari yang lain. "Kewirausahaan pada hakikatnya adalah sifat, ciri, dan watak seseorang yang memiliki kemauan dalam mewujudkan gagasan inovatif ke dalam dunia nyata secara kreatif (Suryana, 2001, p4).

\section{Pengertian Investasi}

Menurut pendapat Basalamah dan Murdifin (2003, p3) "Investasi secara umum diartikan sebagai keputusan mengeluarkan dana pada saat sekarang untuk membeli aktiva riil (tanah, rumah, mobil, dan sebagainya) dengan tujuan untuk mendapatkan penghasilan yang lebih besar di masa yang akan datang.” Investasi merupakan penempatan sejumlah dana pada saat ini dengan harapan untuk memperoleh keuntungan di masa mendatang” (Halim, 2003, p5).

Menurut William F. S. yang dikutip oleh Kasmir dan Jakfar (2008, p4) ”Investasi adalah mengorbankan dollar sekarang untuk dollar di masa yang akan datang." "Investasi dapat pula diartikan penanaman modal dalam suatu kegiatan yang memiliki jangka waktu relatif panjang dalam berbagai bidang usaha” ( Kasmir dan Jakfar ,2008, p4).

Menurut pendapat Sutojo (2000, p1) "Investasi proyek adalah upaya menanamkan faktor produksi langka pada proyek tertentu (baru atau perluasan), pada lokasi tertentu, dalam jangka menengah atau panjang. Faktor produksi langka itu dapat berbentuk: Dana, Kekayaan alam (Natural resources), Tenaga ahli dan tenaga terampil dan Teknologi tingkat madya atau tingkat tinggi."Investasi adalah penanaman modal (baik modal tetap maupun modal tidak tetap) yang digunakan dalam proses produksi untuk memperoleh keuntungan suatu perusahaan" (Sumastuti, 2006, p3). 


\section{Pengertian Studi Kelayakan Bisnis}

Berdasarkan pendapat Umar (2007, p8)”Studi kelayakan bisnis merupakan penelitian terhadap rencana bisni yang tidak hanya menganalisis layak atau tidak layak bisnis dibangun, tetapi juga saat dioperasionalkan secara rutin dalam rangka pencapaian keuntungan yang maksimal untuk waktu yang tidak ditentukan.”

Menurut pendapat Suryana (2003, p140) "Studi kelayakan bisnis adalah suatu penelitian layak atau tidaknya suatu bisnis dilaksanakan dengan menguntungkan secara terus-menerus."

Menurut Kasmir dan Jakfar (2008, p6) ”Studi kelayakan bisnis adalah suatu kegiatan yang mempelajari secara mendalam tentang suatu usaha atau bisnis yang akan dijalankan, dalam rangka menentukan layak atau tidak usaha tersebut dijalankan.”

Menurut pendapat Sutojo (2000, p1) "Studi kelayakan bisnis adalah suatu penelitian yang dilakukan dalam usaha mengetahui layak atau tidaknya suatu proyek bisnis yang biasanya bersangkutan dengan investasi, baik itu untuk bisnis baru maupun untuk pengembangan bisnis.”

\section{Aspek-aspek Penilaian dalam Studi Kelayakan}

Ada beberapa aspek yang perlu dianalisis dalam melakukan studi kelayakan. Masing-masing aspek tidak berdiri sendiri, melainkan saling berkaitan. Artinya, jika salah satu aspek tidak dipenuhi maka perlu dilakukan perbaikan atau tambahan yang diperlukan.

Secara umum prioritas aspek-aspek yang perlu dilakukan studi kelayakan menurut Kasmir dan Jakfar (2008, pp 15-16) adalah sebagai berikut: (a) Aspek Pasar dan Pemasaran; (b) Aspek Manajemen dan Organisasi; (c) Aspek AMDAL; (d) Aspek Hukum; (e) Aspek Ekonomi dan Sosial; (f) Aspek Teknis/Operasi; dan (g) Aspek Keuangan.

\section{Aspek Pasar dan Pemasaran}

Dalam kaitan dengan studi kelayakan suatu usaha atau proyek, aspek pasar dan pemasaran merupakan salah satu aspek yang paling penting. Hal ini disebabkan aspek pasar dan pemasaran sangat menentukan hidup dan matinya suatu perusahaan. Intinya aspek pasar dan pemasaran adalah untuk mengetahui berapa besar pasar yang akan dimasuki, struktur pasar dan peluang pasar yang ada, prospek pasar pada masa yang akan datang serta bagaimana strategi pemasaran yang harus dilakukan (Umar ,2005, p35).

\section{Aspek Manajemen dan Organisasi}

Aspek manajemen dan organisasi merupakan aspek yang cukup penting dianalisis untuk kelayakan suatu usaha. Karena walaupun suatu usaha telah dinyatakan layak untuk dilaksanakan tanpa didukung dengan manajemen dan organisasi yang baik, bukan tidak mungkin akan mengalami kegagalan. Adapun fungsi-fungsi manajemen menurut Kasmir dan Jakfar (2008, pp 161-162) adalah: (1) Perencanaan (Planning), (2) Pengorganisasian (Organizing), (3) Pelaksanaan (Actuating), dan (4) Pengawasan (Controlling)

\section{Aspek Analisis Dampak Lingkungan Hidup (AMDAL)}

Studi ini di samping untuk mengetahui dampak yang akan timbul, juga mencarikan jalan keluar untuk mengatasi dampak tersebut. Studi ini dikenal dengan nama Analisis Dampak Lingkungan Hidup (AMDAL). Pengertian AMDAL menurut PP No.27 Tahun 1999 Pasal 1 yang di kutip oleh Kasmir dan Jakfar (2008, p204) ”AMDAL adalah telaahan secara cermat dan mendalam tentang 
dampak besar dan penting suatu rencana usaha dan kegiatan.” Adapun komponen lingkungan hidup yang harus dipertahankan dan dijaga serta dilestarikan fungsinya menurut Kasmir dan Jakfar (2008, p 204) antara lain: hutan lindung, hutan konservasi, dan cagar biosfer; sumber daya manusia; keanekaragaman hayati; kualitas udara; warisan alam dan warisan budaya; kenyamanan lingkungan hidup; nilai-nilai budaya yang berorientasi selaras dengan lingkungan hidup.

\section{Aspek Hukum}

Tujuan dari aspek hukum adalah meneliti keabsahan, kesempurnaan, dan keaslian dari dokumen-dokumen yang dimiliki. Penelitian ini sangat penting mengingat sebelum usaha tersebut dijalankan, maka segala prosedur yang berkaitan dengan izin-izin atau berbagai persyaratan harus terlebih dahulu sudah terpenuhi.

\section{Aspek Ekonomi dan Sosial}

Secara garis besar dampak dari aspek ekonomi dengan adanya suatu usaha atau investasi menurut Kasmir dan Jakfar (2008, pp 194-196) antara lain: dapat meningkatkan ekonomi rumah tangga; menggali, mengatur, dan menggunakan ekonomi sumber daya alam; Meningkatkan perekonomian pemerintah baik lokal maupun regional; dan pengembangan wilayah.

Dampak sosial dengan adanya suatu proyek atau investasi antara lain menurut Kasmir dan Jakfar (2008, pp 196-197) adalah adanya perubahan demografi; perubahan budaya; perubahan kesehatan masyarakat.

\section{Aspek Teknis/Operasi}

Aspek teknis/operasi juga dikenal sebagai aspek produksi. Analisis pada aspek operasi adalah untuk menilai kesiapan perusahaan dalam menjalankan usahanya dengan menilai masalah ketepatan penentuan lokasi, luas produksi, tata letak (Layout), penyusunan peralatan pabrik dan proses produksinya termasuk pemilihan teknologi. Secara keseluruhan aspek operasi ini akan dinilai bekerja secara efisien atau tidak, karena pada akhirnya efisiensilah yang akan menentukan salah satu faktor besar kecilnya laba yang akan diperoleh perusahaan.

\section{Aspek Keuangan}

Tujuan dari menganalisis aspek keuangan dari suatu studi kelayakan proyek bisnis adalah untuk menentukan rencana investasi melalui perhitungan biaya dan manfaat yang diharapkan, dengan membandingkan antara pengeluaran dan pendapatan, seperti ketersediaan dana, biaya modal, kemampuan proyek untuk membayar kembali dana tersebut dalam waktu yang telah ditentukan dan menilai apakah proyek akan dapat berkembang terus.

\section{METODE}

Metode penelitian yang dilakukan adalah metode deskriptif. Menurut Sugiyono (2006, p11), penelitian dengan menggunakan metode deskriptif adalah penelitian yang dilakukan untuk mengetahui nilai variabel mandiri, baik satu variabel atau lebih tanpa membuat suatu perbandingan atau menghubungkan dengan variabel lain. Lihat tabel 2. 
Tabel 2 Operasional Variabel Penelitian

\begin{tabular}{|c|c|c|}
\hline Variabel & Dimensi & Indikator \\
\hline \multirow{8}{*}{$\begin{array}{c}\text { Kelayakan } \\
\text { ekspansi usaha }\end{array}$} & Aspek Penilaian: & \\
\hline & Aspek Hukum & Deskripsi masalah perijinan \\
\hline & Aspek Pasar dan Pemasaran & $\begin{array}{l}\text { - Deskripsi strategi pemasaran } \\
\text { - Meramalkan permintaan }\end{array}$ \\
\hline & Aspek Keuangan & $\begin{array}{l}-\mathrm{PP} \\
\text { - NPV } \\
\text { - IRR } \\
\text { - PI }\end{array}$ \\
\hline & Aspek teknis dan Operasi & - Deskripsi Proses Produksi dan layout \\
\hline & Aspek Manajemen dan Organisasi & $\begin{array}{l}\text { - Deskripsi Manajemen } \\
\text { - Deskripsi Struktur Organisasi } \\
\text { - Sumber Daya Manusia }\end{array}$ \\
\hline & Aspek Ekonomi dan Sosial & $\begin{array}{l}\text { - Evaluasi dampak Ekonomi } \\
\text {-Evaluasi Dampak Sosial }\end{array}$ \\
\hline & Aspek Dampak Lingkungan & -Deskripsi AMDAL \\
\hline
\end{tabular}

\section{Teknik Pengumpulan Data}

Teknik pengumpulan data dilakukan dengan penelitian kepustakaan (Library Research) dengan menganalisis data pasar dan industri dan penelitian lapangan (Field Research) untuk memperoleh data sekunder berupa catatan, berupa laporan keuangan perusahaan dalam suatu periode tertentu.

\section{Kriteria penilaian investasi}

Adapun beberapa kriteria atau metode dalam menentukan kelayakan suatu usaha menurut Kasmir dan Jakfar (2008, pp 98-105) adalah sebagai berikut.

\section{Net Present value (NPV)}

Net Present Value (NPV) atau nilai bersih sekarang merupakan perbandingan antara PV kas bersih (PV of proceed) dengan PV investasi (capital outlays) selama umur investasi. selisih antara kedua PV tersebutlah yang kita kenal dengan NPV. Rumusan yang biasa digunakan dalam menghitung NPV adalah sebagai berikut.

$$
N P V=\frac{\text { Kas Bersih } 1}{(1+r)}+\frac{\text { Kas Bersih } 2}{(1+r)^{2}}+\ldots . .+\frac{\text { Kas Bersih } N}{(1+r)^{N}}-\text { Investasi }
$$

Setelah memperoleh hasil-hasil yang dengan:

NPV positif, maka investasi diterima

NPV negatif, maka sebaiknya investasi ditolak

Untuk mencari discount factor (DF) maka digunakan rumus:

$$
\text { DF (tahun } X)=\frac{1}{(1+r)^{X}}
$$




\section{Internal Rate of Return (IRR)}

Internal Rate of Return (IRR) merupakan alat untuk mengukur tingkat pengembalian hasil intern. Ada dua rumus dalam mencari IRR.

Dimana:

$$
I R R=i_{1}+\frac{N P V_{1}}{N P V_{1}-N P V_{2}} \times\left(i_{2}-i_{1}\right)
$$

$\mathrm{i}_{1}=$ Tingkat bunga 1

$\mathrm{i}_{2}=$ Tingakat bunga 2

$\mathrm{NPV}_{1}=$ Net Present Value 1

$\mathrm{NPV}_{2}=$ Net Present Value 2

$$
I R R=P 1-C 1 \times \frac{P 2-P 1}{C 2-C 1}
$$

Dimana:

$\mathrm{P} 1=$ Tingkat bunga 1

$\mathrm{P} 2=$ Tingkat bunga 2

$\mathrm{C} 1=\mathrm{NPV} 1$

$\mathrm{C} 2=\mathrm{NPV} 2$

Kesimpulan:

Jika IRR lebih besar (>) dari bunga pinjaman, maka diterima

Jika IRR lebih kecil (<) dari bunga pinjaman, maka ditolak.

\section{Profitability Index (PI)}

Profitability Index (PI) atau Benefit and cost ratio (B/C Ratio) merupakan rasio aktivitas dari jumlah nilai sekarang penerimaan bersih dengan nilai sekarang pengeluaran investasi selama umur investasi. Rumusan yang digunakan dalam mencari PI adalah:

$$
P I=\frac{\sum P V \text { Kas bersih }}{\sum P V \text { Investasi }} \times 100 \%
$$

Kesimpulannya:

Apabila PI lebih besar (>) dari 1, maka diterima

Apabila PI lebih kecil $(<)$ dari 1, maka ditolak

\section{HASIL DAN PEMBAHASAN}

PD. PENGGILINGAN PLASTIK XYZ didirikan pada tahun 1984 dan sudah berasaskan hukum menurut Surat Izin Usaha Perdagangan (SIUP) bernomor: 1939/09-02/PM/IX/1988. Perusahaan ini bergerak secara umum dalam industri manufaktur dan secara khusus dalam industri daur ulang plastik yang mengelola limbah plastik sampai menjadi serpihan daur ulang plastik (limbah plastik yang digiling) untuk dijual kembali kepada pabrik pencetak serpihan daur ulang plastik untuk dicetak menjadi biji plastik atau langsung dicetak menjadi barang jadi.

Sejak didirikan, perusahaan ini sudah melakukan ekspansi sebanyak dua kali dengan sejarah sebagai berikut: pada awal berdirinya yaitu tahun 1984-1988 perusahaan belum memiliki Izin Usaha dan berlokasi di Jakarta Utara dengan status tanah sewaan seluas $600 \mathrm{M}^{2}$. Pada tahun 1988 pemilik mendaftarkan perusahaannya ke Departemen Perdagangan sehingga perusahaan ini menjadi berbadan 
hukum yang bernama PD. PENGGILINGAN XYZ. Pada tahun 2000 lokasi perusahaan dipindahkan ke Jakarta Barat dengan status kepemilikan seluas $1200 \mathrm{M}^{2}$. Dan di tahun 2010 perusahaan berencana akan melakukan perluasan lahan di sebelah kanan pabrik tersebut seluas $300 \mathrm{M}^{2}$.

Tujuan didirikannya pabrik penggilingan ini adalah: membantu mengurangi dan mengolah limbah plastik yang sudah tidak terpakai melalui proses pendaurulangan agar limbah tersebut dapat digunakan kembali. Kedua, membantu menciptakan lapangan kerja sehingga dapat membantu mengurangi pengganguran. Ketiga, memperoleh keuntungan dari usaha bisnis yang dijalankan. Keempat, berpartisipasi dalam usaha pengembangan sektor usaha kecil.

\section{Aspek-aspek Penilaian Usaha}

\section{Aspek Pemasaran}

Untuk mempertahankan dan meningkatkan penjualan, aspek pemasaran merupakan aspek yang penting untuk dikaji lebih mendalam. Oleh karena itu, perusahaan harus memilih strategi pemasaran yang tepat, hal ini tidak terlepas dari penentuan segmen, target dan posisi pasar industrial yang tepat.

\section{Segmentasi Pasar (Market Segmentation)}

PD.PENGGILINGAN PLASTIK XYZ bergerak pada industri manufaktur. Pabrik ini tidak memerlukan penggunaan teknologi yang modern, hanya menggunakan mesin giling sederhana dengan kisaran harga yang relatif terjangkau antara 30 juta sampai 60 juta rupiah. Kemampuan pelanggan untuk membeli serpihan daur ulang plastik relatif besar (satuan ton).

\section{Pasar sasaran (Market Targeting)}

Perusahaan yang ingin mengolah serpihan daur ulang plastik menjadi biji plastik dan perusahaan yang ingin mengolah langsung menjadi produk jadi.

\section{Posisi Pasar (Market Positioning)}

Posisi pasar PD. PENGGILINGAN PLASTIK XYZ adalah sebagai pabrik penghasil serpihan daur ulang plastik yang dapat memenuhi kebutuhan pabrik yang mengolah serpihan daur ulang plastik dan menghasilkan serpihan daur ulang plastik yang berkualitas terbaik sehingga pabrik pengolah serpihan plastik dapat mengolah serpihan daur ulang plastik tanpa mengalami kendala. Setelah strategi bersaing dan unsur segmentasi, target dan posisi pasar ditetapkan, maka selanjutnya perlu diselaraskan dengan kegiatan pemasaran lainnya seperti strategi bauran pemasaran (Marketing Mix Strategy).

Strategi produk; produk akhir yang dihasilkan oleh pabrik adalah berupa serpihan daur ulang plastik yang terdiri dari beberapa jenis, yaitu: (a) PP (Poly Prophylene): sering digunakan sebagai kemasan plastik makanan, minuman, botol bayi, sedotan, kantong obat, penutup, pembungkus kartu undangan. Plastik jenis ini umumnya bersifat kakul; (b) HDPE (High Density Polyethylene): plastik jenis ini digunakan untuk botol kosmetik, obat, minuman, tutup plastik, jeriken pelumas, dan cairan kimia. Plastik jenis ini umumnya bersifat lebih elastis jika dibandingkan dengan PP; (c) PP PK: merupakan plastik jenis PP (Poly Prophylene) yang berwarna putih kapur (PK); (d) NASO: merupakan jenis HDPE yang berwarna bening.

Strategi harga; penentuan harga merupakan suatu keputusan yang sangat penting yang harus dilakukan oleh perusahaan. Harga yang ditentukan harus dapat memenuhi semua biaya yang dikeluarkan dan bahkan lebih dari itu yaitu memperoleh laba. Namun perusahaan juga harus menyesuaikan dengan tingkat harga di pasar yang dituju. Harga beli bahan baku pada saat ini adalah: 
Tabel 3 Harga Beli Bahan Baku tahun 2010

\begin{tabular}{|ll|l|}
\hline \multicolumn{2}{|c|}{ PP } & \multicolumn{2}{c|}{ HDPE } \\
\hline Rp & 3.300 & Rp 4.050 \\
\hline
\end{tabular}

Sumber: PD. PENGGILINGAN PLASTIK XYZ

Pada saat ini harga jual produk yaitu:

Tabel 4 Harga Jual Produk tahun 2010

\begin{tabular}{|c|c|c|c|}
\hline PP & HDPE & PP PK & NASO \\
\hline Rp 3.850/KG & Rp 4.750/KG & Rp 6.250/KG & Rp 7.500/KG \\
\hline
\end{tabular}

Sumber: PD. PENGGILINGAN PLASTIK XYZ

Strategi lokasi dan distribusi; dalam hal ini perusahaan langsung menjual produk yang dihasilkannya ke pabrik yang melakukan proses terhadap serpihan daur ulang plastik yang dapat dikatakan sebagai konsumen. Lokasi pabrik yang menjadi konsumen tidak jauh dari lokasi tempat pabrik ini berada, karena usaha ini bertempat di daerah perindustrian.

Strategi promosi; perusahaan ini melakukan promosi dengan memberikan contoh plastik yang dapat dijadikan sampel untuk diproses ke tahap selanjutnya. Sehingga, pabrik pemroses serpihan daur ulang dapat mengetahui kualitas serpihan yang dihasilkan.

\section{Aspek Manajemen dan Organisasi}

Dengan melakukan perluasan pabrik maka perusahaan harus memerhatikan fungsi-fungsi manajemen yang berkaitan dengan kegiatan tersebut agar tujuan perusahaan dapat terwujudkan. Adapun fungsi-fungsi manajemen yang dimaksudkan adalah sebagai berikut.

\section{Perencanaan (Planning)}

Perencanaan perluasan pabrik yang dilakukan bertujuan untuk memenuhi permintaan serpihan daur ulang plastik yang meningkat sehingga menambah laba perusahaan dengan penambahan 1 unit mesin giling, karyawan untuk mengoperasikan mesin, perluasan lahan untuk menempatkan mesin giling tambahan, menyimpan bahan baku dan serpihan daur ulang plastik (produk akhir), tempat untuk pemisahan (sortir), tempat mencuci serpihan daur ulang plastik dan tempat untuk menjemur serpihan daur ulang plastik setelah dicuci.

\section{Pengorganisasian (Organizing)}

Tugas dan tanggung jawab dari struktur organisasi perusahaan adalah sebagai pemilik; tugas dan tanggung jawabnya adalah: memimpin, mengoordinasikan, mengawasi dan mempertanggung jawabkan seluruh kegiatan perusahaan baik kegiatan produksi dan non-produksi yang terjadi di pabrik; menentukan keputusan taktis dan strategis yang berkaitan dengan perusahaan di masa yang akan datang dan memperhatikan kondisi perusahaan baik material maupun tenaga kerja; melakukan perekrutan dan seleksi karyawan baru.

Tugas dan tanggung jawab bagian Operasi adalah: mengawasi seluruh kegiatan produksi perusahaan; menentukan pekerjaan yang harus dilakukan oleh buruh; mengarahkan karyawan jika terjadi penyimpangan dalam melaksanakan pekerjaannya; bertanggung jawab untuk mengontrok 
keluar masuknya bahan baku maupun barang hasil olahan; memotivasi karyawan untuk meningkatkan produksi dan kebersihan produk; memberikan laporan secara periodik kepada pemilik perusahaan tentang seluruh kegiatan perusahaan; bekerja sama dengan bagian keuangan dan pemasaran untuk melakukan penyusunan jadwal pengangkutan bahan baku dari lapak dan mengirim barang hasil olahan ke pabrik yang melakukan pemesanan barang.

Tugas dan tanggung jawab bagian Keuangan adalah: melakukan pencatatan terhadap seluruh kegiatan yang menyangkut arus kas perusahaan; melakukan kegiatan yang berhubungan dengan transaksi keluar masuknya kas perusahaan; bekerja sama dengan bagian operasi dan pemasaran untuk melakukan penyusunan jadwal pengangkutan bahan baku dari lapak dan mengirim barang hasil olahan ke pabrik yang melakukan pemesanan barang; melakukan kegiatan yang berkaitan dengan administrasi perusahaan; melakukan penimbangan barang yang masuk, barang yang selesai di olah dan barang yang akan dikirim ke pabrik yang melakukan pemesanan barang; membuat laporan yang berkaitan dengan keuangan dan administrasi perusahaan untuk diserahkan kepada pemilik perusahaan; bekerja sama dengan bagian pemasaran mengenai hal yang berkaitan dengan penagihan piutang.

Tugas dan tanggung jawab bagian Pemasaran adalah: memasarkan produk kepada pelanggan dan berusaha mencari pelanggan baru, serta menjaga hubungan baik dengan pelanggan; bekerja sama dengan bagian operasi dan keungan untuk melakukan penyusunan jadwal pengangkutan bahan baku dari lapak dan mengirim barang hasil olahan ke pabrik yang melakukan pemesanan barang; melakukan pengawasan terhadap bahan baku yang di angkut dari lapak dan barang hasil olahan yang dikirim ke pabrik agar barang yang dikirimkan atau di angkut sampai ke tempat tujuan tepat waktu dan kondisi barang tetap terjaga; menjaga hubungan baik dengan pemasok dan mencari pemasok baru agar bahan baku yang diperoleh semakin meningkat baik kualitas maupun kuantitasnya; melakukan penagihan piutang dagang dan melakukan kegiatan yang berhubungan dengan perbankan perusahaan; bertanggung jawab untuk mencapai target penjualan yang ditetapkan oleh pemilik.

Tugas dan tanggung jawab Buruh adalah: bertanggung jawab melaksanakan tugas yang telah diberikan oleh bagian operasi; melakukan pensortiran terhadap limbah berdasarkan jenis dan warna limbah; melakukan pembongkaran terhadap truk yang mengangkut bahan baku dan penyusunan barang hasil olahan terhadap truk yang akan melakukan pengiriman barang ke pabrik.

\section{Pelaksanaan (Actuating)}

Dalam menjalankan perusahaan organisasi para pimpinan/ manajer harus menggerakkan bawahannya untuk mengerjakan pekerjaan yang telah ditentukan dengan cara memimpin, memberi perintah, memberi petunjuk dan memberi motivasi.

\section{Pengawasan (Controlling)}

Dalam operasi perusahaan, seluruh kegiatan produksi di awasi oleh seorang mandor dari bagian operasional. Pengawasan yang dilakukan adalah kegiatan mengukur dan menilai pelaksanaan operasi perusahaan apakah telah sesuai dengan rencana. Jika dalam operasi perusahaan terjadi penyimpangan, maka akan segera dikendalikan oleh mandor yang bertugas. 
Jumlah gaji dan tenaga kerja yang ada saat ini adalah:

Tabel 5 Tabel Daftar Gaji

\begin{tabular}{|c|c|c|}
\hline Tugas & Jumlah & Gaji \\
\hline Buruh sortir (borongan) & & Rp 50,-/ KG \\
\hline Buruh (harian) & & Rp 30.000/ hari \\
\hline Sopir & & Rp 1.310.000/ bulan + Rp 6.000/ hari \\
\hline Kernet & & Rp 640.000/ bulan + Rp 5.000/ hari \\
\hline Bagian pemasaran & & Rp 1.400.000/ bulan \\
\hline Bagian Operasional & & Rp 1.500.000/ bulan \\
\hline Bagian Keuangan & & Rp 1.300.000/ bulan \\
\hline
\end{tabular}

\section{Aspek dampak lingkungan (AMDAL)}

Untuk mengurangi dampak pencemaran lingkungan dari limbah hasil pencucian serpihan daur ulang plastik maka perusahaan melakukan pengerukan pada selokan di sekitar pabrik setiap periode tiga bulan sekali, sehingga dampak pencemaran lingkungan dapat diminimalisir dan tidak terjadi penyumbatan pada saluran air di sekitar lingkungan pabrik. Agar tidak mengganggu lingkungan sekitar akibat timbulnya suara mesin penggilingan, maka mesin penggilingan ditempatkan di bagian dalam pabrik yang jauh dari lingkungan luar, sehingga lingkungan sekitar pabrik tidak terganggu oleh kebisingan mesin penggilingan. Karena terletak di daerah perindustrian masalah masalah lingkungan akibat operasi pabrik maupun proyek perluasan lokasi pabrik tidak terlalu banyak timbul.

\section{Aspek Hukum}

PD. PENGGILINGAN PLASTIK XYZ didirikan pada tahun 1984 dan sudah berasaskan hukum menurut Surat Izin Usaha Perdagangan (SIUP) bernomor: 1939/09-02/PM/IX/1988 dengan nomor NPWP (Nomor Pokok Wajib Pajak): 6.267.202.7-20. Untuk masalah kepemilikan lahan yang ingin digunakan menurut Gitaya (2009) berdasarkan UU Nomor 21/1997 sebagaimana telah diubah terakhir dengan UU Nomor 20/2000 ditetapkan bahwa pemindahan hak karena jual beli dikenakan Bea Perolehan Hak Atas Tanah dan/atau Bangunan (BPHTB) sebesar 5\% dari Nilai Perolehan Objek Pajak Kena Pajak (NPOPKP), yaitu Nilai Perolehan Objek Pajak (NPOP) setelah dikurangi Nilai Perolehan Objek Pajak Tidak Kena Pajak (NPOPTKP) pada saat tanggal dibuat dan ditandatanganinya akta.

Tarif pajak penghasilan yang dikenakan adalah:

Tabel 6 Tabel Tarif Pajak Penghasilan

\begin{tabular}{lc}
\hline Penghasilan & Tarif pajak \\
\hline Sampai dengan 50 juta & $10 \%$ \\
50 juta -100 juta & $15 \%$ \\
100 juta keatas & $30 \%$ \\
\hline
\end{tabular}

Sumber: dudiwahyudi.com

\section{Aspek Ekonomi dan Sosial}

Setiap kegiatan usaha yang dilakukan pasti akan memberikan dampak di bidang ekonomi dan sosial. Dampak dari kegiatan usaha yang dilakukan dapat dirasakan oleh berbagai pihak, baik dari pihak yang menjalankan usaha, pemerintah maupun masyarakat daerah sekitar. Secara umum dampak di bidang ekonomi dan sosial dengan adanya perluasan pabrik adalah: membuka lapangan kerja bagi 
masyarakat, sekaligus mengurangi jumlah pengangguran; meningkatkan pendapatan daerah dan meningkatkan taraf hidup bagi masyarakat daerah sekitar; meningkatkan pendapatan pemerintah dari pajak penghasilan yang dikenakan pada perusahaan; membantu mengurangi dan mengolah limbah plastik yang sudah tidak terpakai melalui proses pendaurulangan agar limbah tersebut dapat digunakan kembali.

\section{Aspek Teknis/Operasi}

Dalam melakukan ekspansi pabrik maka penilaian terhadap aspek teknis/operasi meliputi proses produksi, lokasi ekspansi, penentuan luas produksi, layout pabrik, pemilihan teknologi.

\section{Proses Produksi}

Proses produksi dilakukan dengan mengangkut limbah plastik yang diperoleh dari lapaklapak penampung limbah plastik dengan menggunakan truck colt diesel. Kemudian sebelum memasuki tahap produksi barang mengalami proses penampungan terlebih dahulu. Untuk menampung limbah diperlukan tempat yang luas. Dalam proses penampungan barang akan dikelompokan secara umum menurut jenis barang, lalu akan disortir oleh karyawan bagian pensortiran yang sudah ditugaskan menurut jenis barang.

Tahap awal proses produksi dapat dikatakan proses pensortiran yaitu tahap pemisahan limbah-limbah plastik menjadi kelompok warna dan jenis barang yang lebih spesifik dan membuang material/ benda asing yang tidak diharapkan masuk ke dalam proses penggilingan. Selama proses pensortiran bahan baku akan mengalami penyusutan sebesar 5\%. Tahap selanjutnya yaitu menggiling limbah plastik dengan menggunakan mesin penggilingan sehingga limbah plastik tersebut berubah menjadi serpihan daur ulang plastik, setelah itu serpihan daur ulang plastik mengalami proses pencucian dan penjemuran, dan yang terakhir serpihan daur ulang plastik dimasukan ke dalam karung berukuran $70 \mathrm{cmX} 100 \mathrm{~cm}$ untuk di jual ke pabrik penghasil biji plastik atau barang jadi untuk di proses.

\section{Lokasi Ekspansi}

Perluasan lokasi pabrik dilakukan tepat disebelah kanan pabrik. Hal ini dikarenakan lokasi pabrik saat ini sudah cukup strategis, karena pabrik berlokasi di daerah industri dimana dekat dengan penyedia bahan baku, dekat dengan pabrik yang berlanggan, dekat dengan lokasi sumber daya yang diperlukan perusahaan, lokasi yang mudah di akses sehingga memudahkan keluar masuk kendaraan yang akan beroperasi mengangkut limbah atau mengirim produk hasil penggilingan produk. Karena terletak di daerah industri yang jauh dari pemukiman penduduk sehingga masalah lingkungan tidak terlalu banyak timbul

\section{Penentuan Luas Produksi}

Dikarenakan permintaan serpihan daur ulang plastik yang terus meningkat sampai melebihi kapasitas normal mesin penggilingan maka perlu ditambahkan sebuah mesin penggilingan. Kapasitas normal mesin penggilingan adalah 250.000KG/ kwartal tahunan waktu operasi mesin 8 jam/ hari. Sehingga jika dilakukan penambahan mesin kapasitas normal dari kedua mesin adalah 500.000KG/ kwartal.

\section{Layout Pabrik}

Agar operasi pabrik dapat berjalan secara optimal maka penggunaan lahan harus dapat mendukung proses produksi yang paling efisien namun tetap efektif. Agar proses produksi berjalan dengan lancar maka perlu adanya keterkaitan penempatan lokasi untuk setiap proses produksi. Berikut adalah denah tata letak pabrik pada saat sebelum melakukan ekspansi pabrik. 


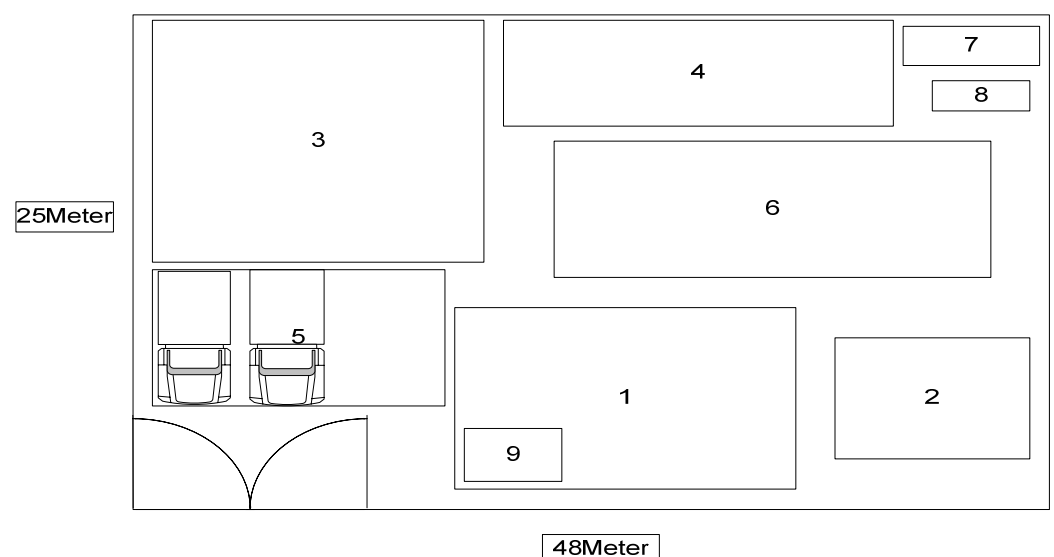

Gambar 1 Denah Tata Letak Pabrik sebelum Perluasan Sumber: PD. PENGGILINGAN PLASTIK XYZ

\section{Keterangan:}

1. Gudang serpihan daur ulang plastik

2. Tempat istirahat/ tempat tidur pekerja

3. Tempat penyimpanan bahan baku

4. Tempat pensortiran

5. Tempat Parkir kendaraan

6. Tempat penjemuran serpihan daur ulang plastik

7. Tempat penggilingan barang

8. Tempat pencucian serpihan daur ulang plastik

9. Kantor

Perencanaan tata letak pabrik setelah ekspansi pabrik dilaksanakan:

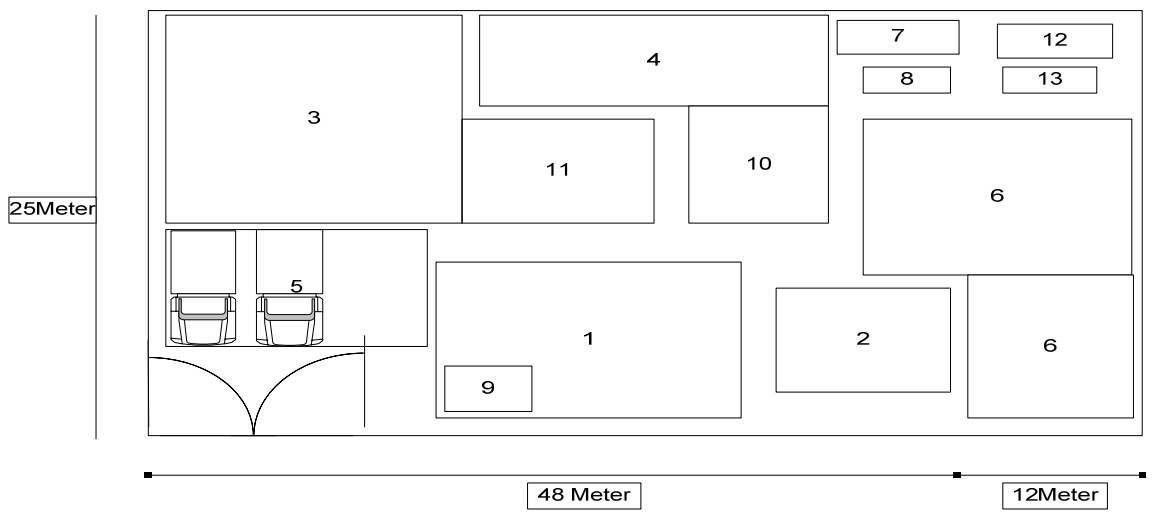

Gambar 2 Denah Tata Letak Pabrik untuk Rencana Perluasan Lahan Sumber: PD. PENGGILINGAN PLASTIK XYZ

\section{Keterangan:}

1. Gudang serpihan daur ulang plastik

2. Tempat istirahat/tempat tidur pekerja

3. Tempat penyimpanan bahan baku

4. Tempat pensortiran

5. Tempat Parkir kendaraan 
6. Tempat penjemuran serpihan daur ulang plastik yang baru

7. Tempat penggilingan barang

8. Tempat pencucian serpihan daur ulang plastik

9. Kantor

10. Tambahan tempat pensortiran

11. Tambahan tempat penyimpanan bahan baku

12. Tempat mesin penggilingan yang baru

13. Tempat pencucian serpihan daur ulang plastik yang baru

\section{Pemilihan Teknologi}

Usaha yang dilakukan dapat dikatakan menggunakan teknologi padat karya, karena dalam proses produksi hanya menggunakan sebuah mesin penggilingan yang dioperasikan oleh tenaga manusia. Karena menggunakan teknologi padat karya, perusahaan ini lebih banyak menggunakan tenaga manusia sehingga lebih banyak menyerap tenaga kerja.

Proses produksi pada pabrik ini tergolong ke dalam Continue Process karena proses produksi pabrik menghasilkan volume output yang besar, sifat operasinya berulang-ulang sehingga dapat mencapai optimasi dan efisiensi yang tinggi dalam penggunaan sumber daya dan proses produksinya sama untuk setiap barang yang dihasilkan.

\section{Aspek Keuangan (Sumber Dana dan Biaya Modal)}

Biaya pra-investasi; dalam melaksanakan transaksi jual beli dikenakan bea perolehan hak atas tanah sebesar 5\% dari nilai perolehan tanah (Rp 700.000.000,-) yaitu sebesar Rp 35.000.000,-Kebutuhan dana untuk penambahan aktiva tetap; aktiva tetap berwujud dianggarkan sebesar Rp 805.000.000,-. Aktiva tetap berwujud meliputi:

a. Tanah dan bangunan Rp 750.000.000,-

b. Mesin penggilingan plastik Rp 55.000.000,-

Jumlah dana Investasi; dengan demikian jumlah keseluruhan dana rencana ekspansi pabrik pada perusahaan penggilingan plastik ini adalah:

Jumlah dana investasi $=$ dana pra-investasi + dana modal penambahan aktiva tetap

Jumlah dana investasi $=\mathrm{Rp} 35.000 .000,-+$ Rp 805.000.000,-

$$
=\operatorname{Rp} 840.000 .000,-
$$

\section{Sumber dana}

Dalam proyek ekspansi pabrik ini untuk mengetahui biaya modal atas dana yang digunakan yaitu berasal dari modal sendiri, maka perhitungan biaya modal atas modal sendiri ditentukan berdasarkan penilaian internal perusahaan. Menurut pihak internal perusahaan, biaya modal yang dibebankan atas pemanfaatan modal sendiri berdasarkan tingkat pengembalian yang diharapkan. Berdasarkan ketentuan perusahaan dimana tingkat bunga pengembalian yang diharapkan sebesar $20 \%$.

\section{Metode Penilaian Investasi}

Beberapa metode yang dipakai dalam menghitung kelayakan perluasan pabrik dari aspek keuangan adalah Metode Payback Period (PP), Net Present Value (NPV), Internal Rate of Return (IRR), dan Profitability Index (PI) dengan menggunakan tiga skenario yaitu skenario moderat, skenario optimis dan skenario pesimis. Hasil analisis dicantumkan ke dalam tabel berikut. 
Tabel 7 Hasil Analisis Keuangan

\begin{tabular}{rllllc}
\hline & & \multicolumn{4}{c}{ Skenario } \\
\cline { 3 - 6 } No & Metode & \multicolumn{1}{c}{ Moderat } & \multicolumn{1}{c}{ Pesimis } & \multicolumn{1}{c}{ Optimis } & Keputusan \\
\hline 1 & $P P$ & 1 Tahun 7 Bulan 2 hari & 3 Tahun 5 Bulan 9 hari & 1 Tahun 1 Bulan 17 hari & Diterima \\
2 & $N P V$ & Rp 1.813.576.144,- & Rp -91.105.152,- & Rp 4.058.418.036,- & Diterima \\
3 & $I R R$ & $78,45 \%$ & $15,12 \%$ & $125,01 \%$ & Diterima \\
4 & $P I$ & 3,16 & 0,891 & 5,314 & Diterima \\
\hline
\end{tabular}

Sumber: Data perusahaan yang diolah

Untuk rencana pengembangan usaha berdasarkan hasil analisis sensitifitas, jika rencana pengembangan menggunakan skenario moderat maka rencana pengembangan usaha ini layak untuk dilaksanakan, dan jika menggunakan skenario optimis dinyatakan lebih layak lagi untuk dilaksanakan. Jika menggunakan skenario pesimis rencana pengembangan usaha ini tidak layak untuk dilaksanakan. Tetapi kemungkinan besar dengan kondisi permintaan produk yang terus meningkat sehingga kapasitas produksi melebihi kapasitas normal, target inflasi pada tahun mendatang yang di targetkan sekitar 4\%-6\% (Daniel, 2010). Dengan demikian skenario moderat dan optimis sangat mungkin terjadi, sedangkan skenario pesimis sedikit kemungkinannya untuk terjadi

\section{SIMPULAN}

Aspek non-keuangan, terdiri dari: 1) aspek hukum: Perusahaan sudah berasaskan hukum; aspek pasar dan pemasaran: Permintaan produk yang terus meningkat dan hasil peramalan yang juga meningkat; aspek teknis dan operasi: Penggunaan teknologi yang terjangkau dan padat karya; 2) aspek manajemen dan organisasi: Dengan struktur organisasi yang sederhana dan deskripsi pekerjaan dengan uraian tugas, wewenang dan tanggung jawab yang cukup jelas; 3) aspek Ekonomi dan Sosial: Membuka lapangan pekerjaan baru, membantu mengolah limbah plastik; 4) aspek AMDAL: Limbah yang tidak membahayakan lingkungan sekitar. Aspek Keuangan; berdasarkan hasil perhitungan dengan metode $P P, N P V$, IRR, PI maka skenario optimis dan moderat layak untuk dijalankan. Rekomendasi untuk perusahaan adalah agar perusahaan diharapkan dapat menjalankan perluasan pabrik dengan langkah-langkah menambah lahan dan selanjutnya melakukan proses bisnis (merekrut, menambah mesin dan menambah jumlah pemasok bahan baku).

\section{DAFTAR PUSTAKA}

BPS (2009), Pertumbuhan Ekonomi Indonesia Kwartal II 2009 Mencapai 2.3 Persen, (ON-LINE), http://www.bps.go.id/aboutus.php?search=1, 15 Oktober 2009.

Daniel, W. (2009). SBY: Pertumbuhan Ekonomi RI Termasuk yang Tertinggi di Dunia. (ON-LINE), $\begin{array}{llll}\text { diakses } & 15 & \text { Oktober } & 2009 \\ \end{array}$ http://www.detikfinance.com/read/2009/01/05/111209/1063065/4/sby-pertumbuhanekonomi-ri-termasuk-yang-tertinggi-di-dunia.

Daniel, W. (2010). Target Inflasi 2010 Naik Sedikit. diakses 20 Desember 2009 dari http://www.detikfinance.com/read/2009/06/04/084014/1142425/4/target-inflasi-2010-naiksedikit.

Fuad, M., Christin H., Nurlela, Sugiarto dan Paulus, Y.E.F. (2005). Pengantar Bisnis. Edisi-4. Jakarta: Gramedia Pustaka Utama. 
Gitaya, W. S. (2009), Pajak atas Penjualan Tanah, diakses 17 Desember 2009 dari http://www.detikfinance.com/read/2009/05/08/100246/1128182/691/pajak-atas-penjualantanah.

Halim, A. (2003). Analisis Investasi. Jakarta: Salemba Empat.

Heizer, J., dan Render, B. (2004). Manajemen Operasi. Edisi ketujuh. Jakarta: Salemba Empat.

Hendro dan Chandra W.W. (2006). Be Smart and Good Entrepreneur. Edisi-1. Jakarta: CLA Publishing dan Universitas Bina Nusantara.

Husnan, S., dan Suwarsono, M. (2000). Studi Kelayakan Proyek. Edisi-4. Yogyakarta: Unit Penerbit.

Kamaluddin. (2004). Studi Kelayakan Bisnis. Malang: Dioma.

Kasmir dan Jakfar. (2008). Studi Kelayakan Bisnis. Edisi-2. Jakarta: Kencana Prenada Media Group.

Kasmir. (2006). Kewirausahaan. Edisi-1. Jakarta: Rajawali Pers.

Longenecker, J. G., Moore, C.W., dan Petty, J. W. (2001). Kewirausahaan Manajemen Usaha Kecil. Edisi-11. Jakarta: Salemba Empat.

Mukono, H. J. (2005). Kedudukan AMDAL Dalam Pembangunan Berwawasan Lingkungan yang $\begin{array}{lllll}\text { Berkelanjutan. } & \text { Diakses } & 15 & \text { Oktober } & 2009 \\ \end{array}$ http://www.journal.unair.ac.id/filerPDF/KESLING-2-1-03.pdf.

Murdifin, H. dan Basalamah, S. (2003). Studi Kelayakan Investasi Proyek dan Bisnis. Edisi-1. Jakarta: PPM.

Sekaran, U. (2006). Metodologi Penelitian untuk Bisnis. Jakarta: Salemba Empat.

Soeharto, I. (2002). Studi Kelayakan Proyek Industri. Jakarta: Erlangga.

Sugiyono. (2006). Metode Penelitian Bisnis. Bandung: Alfabeta.

Sumastuti, AM. (2006), Keunggulan NPV sebagai Alat Analisis Uji Kelayakan Investasi dan Penerapannya, (ON-LINE), http://jurnal.bl.ac.id/wp-content/uploads/2007/01/BEJ-v3-n1artikel7-agustus2006.pdf , 07 Januari 2010.

Suratman. (2001). Studi Kelayakan Proyek Teknik dan Prosedur Penyusunan Laporan. Yogyakarta: JNJ Learning.

Suryana. (2003). Kewirausahaan. Edisi-1. Jakarta: Salemba Empat.

Sutojo, S. (2000). Studi Kelayakan Proyek: Konsep, Teknik dan Kasus. Edisi-1. Jakarta: Damar Mulia Pustaka.

Tunggal, A. W. (2004). Manajemen Kewirausahaan. Jakarta: Harvarindio.

Umar, H. (2007). Studi Kelayakan Bisnis. Edisi-3. Jakarta: Gramedia Pustaka Utama.

Wahyudi, D. (2008). Tarif Pajak Penghasilan. Diakses 19 Desember 2009 dari http://dudiwahyudi.com/pajak/pajak-penghasilan/tarif-pajak-penghasilan.html.

Zimmerer, T. W. dan Scarborough, N. M. (2004). Pengantar Kewirausahaan dan Manajemen Bisnis Kecil. Edisi-2. Jakarta: Index. 